\title{
Coaching MSMEs through the Business Development Services Program
}

\author{
https://doi.org/10.25008/parahita.v1i1.37 \\ Panji Putranto ${ }^{1}$, Meiliyah Ariani2* \\ ${ }^{1}$ Faculty of Economics and Business, Mercubuana University \\ J1. Rawa Dolar No. 45, Jatisampurna, Bekasi 17433 - Indonesia \\ ${ }^{2}$ Faculty of Economics and Business, Prof. Dr. Moestopo University (Beragama) \\ J1. Hang Lekir I No. 8 Jakarta 10270 - Indonesia \\ *Email Korespondensi: meiliyahariannie@yahoo.co.uk
}

\begin{abstract}
The Government pays attention to the development of Micro, Small, Medium Enterprises (MSMEs) to increase competition, develop technology, create diverse markets, increase employment opportunities, production output and the contribution to the country. The government is aware of its importance as a source of poverty reduction, growth in GRDP. Government collaborating with parties expected to increase the enthusiasm of those who have declined. Collaboration between agencies through Business Development Service have long-term goals. Students expected to understand the role of taxes. For university, can be a means of community service and contribute to the institution accreditation standards 7.6 and 7.7. Whereas for SMEs with one hundred target, can improve managerial skills. With the support of E-Commerce, digital training technology transfer, MSMEs can sell through website and manage finance with android. Research Irfan Fatoni, Indah Dewi Nurhayati "Analysis of BDS harmony -Provider (BDSP) with Government Regulations Regarding MSMEs Development in East Java (2014), only discussed the harmony achieved by BDS-P, not cooperation between parties. Community service are carried out by field surveys, interviews with MSMEs in Pondok Melati. BDS carried out in tax workshops, BDS socialization, E-Commmerce, simple bookkeeping, brand image training and bazaar encourages MSMEs to grow, develop. So that small households can prosper independently and reduce the burden of government. By following a year continuous assistance, non-productive can become productive, professional MSMEs. This is evidenced by the formation of MSMEs management with provision of independent equipment following bazaars. Closer to the ideals of MSME villages in Pondok Melati.
\end{abstract}

Keywords: Micro Business, Small Business, Medium Business, Business Development Services, EFilling.

\section{INTRODUCTION}

The low realization in tax revenue is partly caused by the problem of obedience of taxpayers who do not deliver obligations as they should. Government Regulation Number 23 of 2018 is a regulation concerning income from businesses obtained by taxpayers who have a certain gross circulation within one tax year. This PP takes effect on July 1, 2018. The new income tax rate for MSMEs/UMKM is $0.5 \%$ of the turnover. The regulation replaces the previous regulation, namely PP No. 46 of 2013 with a UMKM final PPh rate of 1 percent calculated based on gross income (turnover) is intended for MSMEs whose turnover is less than Rp. 4.8 billion within a year. So with the change of regulations that favor MSMEs, it is expected that the number of MSMEs will continue to increase and help with tax revenue realization. This is one of the reason for this research.

The development of SMEs in the District of Pondok Melati, Bekasi is faced with various problems. These problems are management irregularities and limited capital, inadequate human resources and difficulties in marketing, also difficulties in the process of recording and calculating funds to carry out tax payment obligations. These things are experienced by SMEs 
in the District of Pondok Melati. It is necessary to make appropriate activities to support MSMEs, among others: business feasibility assessment training, marketing, fund management, simple bookkeeping, business licensing, and tax obligations.

In Sri Lanka, the government supports a combination package of credit and BDS programs to develop MSMEs and have an impact on the number of new MSMEs that have sprung up. Likewise in Ethiopia, where the government is making a BDS strategy and understands the importance of MSMEs as a resilient sector from the economic crisis. In these countries, one of the basic obstacles faced is the lack of knowledge/literation for productive people on what is needed to build MSMEs (Minda Yirga Beyene, 2018).

MSME is one of the industrial sectors that are not affected by the global crisis that hit the world. With this evidence, it is clear that MSMEs can be taken into account in increasing market competitiveness and stabilizing the existing economic system. With greater policies and support such as licensing, technology, structure, management, training and financing, SMEs are expected to develop rapidly and be able to compete with large markets in the midst of free markets that are happening right now. In addition, MSMEs are expected to increase people's income, open up employment opportunities and prosper the community as a whole so as to create competitiveness and good stability of the Indonesian economy.

With the increasing number and growth of MSMEs, it is expected to contribute to increasing tax revenue. Related to MSMEs, the Directorate General of Taxes analyzes the potential for tax revenue from MSMEs. The contribution of the business sector to the total gross domestic product (GDP) is estimated at $61.9 \%$. However, in terms of state revenue so far, the MSME sector only contributes for around 5\% of total tax revenue. If seen from their role in gross domestic income (GDP), this indicates that there is still potential that can be explored, or even many MSMEs that have not registered themselves as taxpayers.

The MSME-based economy is better because this business absorbs a lot of labor, relatively small capital. In addition, MSMEs are also able to increase creativity for people who want to have more income and at the same time characterize the identity of an area from its production results. The government realizes the importance of MSMEs, not only as one of the important sources of poverty reduction in Pondok Melati sub-district, but also as a source of growth in Gross Regional Domestic Product (GDP).

Mercubuana University Campus D Kranggan Bekasi took the initiative to carry out BDS activities by cooperating with the KPP Pratama Pondok Gede, Pondok Melati Subdistricts and the BRI Bank Pondok Gede branch with the theme "Development of Small and Medium Enterprises (SMEs) through the Business Development Services (BDS) Program". This activity is expected to be a solution to improve the skills of MSME persons and become a driving force for growth and increase in the number of MSMEs in particular, the Pondok Melati region, as well as being a form of state defense supporting the realization of taxation. Micro, Small and Medium Enterprises (MSMEs) players have an important role to play in the economic sustainability of a region. MSMEs that grow and develop will have a major impact on nation-building through the tax contributions they pay.

The Pratama Pondok Gede Tax Service Office (KPP) understands very well the contribution of MSMEs in building the nation through the taxes they pay. Therefore, this real sector business unit receives assistance and guidance through a number of trainings and socialization. Among them SME socialization and training in the Pondok Melati region. KPP Pratama Pondok Gede has an interest so that MSMEs in Bekasi City can grow, develop and have an awareness of paying their tax obligations.

Business Development Services Program (BDS) with four parties contributors namely Mercubuana University Campus D Kranggan Bekasi, KPP Pratama Pondok Gede, Pondok Melati District and BRI Bank Pondok Gede branch and supported by the Cooperative and UMKM Office is the first form of collaboration between the parties in Indonesia for BDS 
collaboration of a kind (most widely parties). Plus students and staff of Mercubuana University Campus D Kranggan Bekasi are actively involved in this activity. In the research of Irfan Fatoni and Indah Dewi Nurhayati with the title "Analysis of Business Development Service Harmony - Provider Program (BDSP) with Government Regulations Related to the Development of MSME in East Java (2014), researchers only discussed the harmony achieved by each BDS-P but not yet in the context of cooperation between parties as the UMKM Trustees.

It is expected that with the BDS program activities with the cooperation agreement between the first four parties in Indonesia, as well as the ideals of realizing the Pondok Melati MSME village, it will be able to further enhance the managerial skills of the MSME persons which ultimately contribute to the increased realization of tax revenue in the MSME sector. Managerial skills will be acquired by SMEs persons through training provided by BDS program contributors. The forms of training that can be obtained include simple bookkeeping training for MSMEs provided by accounting study program lecturers, e-commerce training or selling through websites by computer science study programs, brand image training by creative art design study programs. Digital training and internet marketing as well as business feasibility and financial management by a lecturer in management studies at Mercu Buana University Campus D Kranggan Bekasi. Besides that, Mercu Buana University Campus D Kranggan Bekasi also organizes profit and loss calculation training using an android application that can be installed by UMKM participants.

The objectives to be achieved in this activity are: (1) Providing the opportunity to fulfill the tri dharma in the form of community service research for Mercu Buana University lecturers especially in campus D Kranggan Bekasi which contributes to the accreditation forms of standards 7.6 and 7.7, in the form of training to improve the skills of MSME practitioners. , regarding business valuation/ business feasibility, strategies to improve business/ digital marketing by utilizing social networking and e-commerce, good capital management and financial records, as well as simple bookkeeping; (2) Increase insight and motivation for Mercu Buana University students, especially in Campus D Kranggan who are included in the activity to be more active in their fields after getting education and teaching from the lecturers concerned; (3) Providing knowledge and understanding of tax obligations, calculation and tax reporting to SMEs, with counseling given by KPP Pratama Pondok Gede; (4) Providing knowledge and understanding of licensing to SMEs practitioners; (5) Providing knowledge and understanding of banking products such as the People's Business Credit (KUR).

\section{METHODS}

This dedication activity is carried out by means of field surveys and interviews with SMEs in the District of Pondok Melati. There are many MSME persons who need guidance in business management. Mercu Buana University Campus D in collaboration with Pondok Gede Bekasi City Tax Office through the Business Development Service Program (BDS) conducted community service activities by organizing MOU Signing, Tax Workshop, Business Development Services (BDS) socialization, E-Commmerce Training, Bookkeeping Training Simple, Brand Image/ Visual Training and SME bazaar activities.

The signing of the MoU and the E Filling and NPWP Tax Workshop were held on Thursday, February 15, 2017 at 09.00 to 12.30 WIB in the meeting room and the Hall of Mercu Buana University Campus D, Kranggan, Bekasi (shown in Fg.1). The Business Development Services socialization was held on Thursday, March 22, 2018, at 09.00-12.00 at the Pondok Melati District office, Jl. Perum Chandra Indah Jatirahayu Market. 


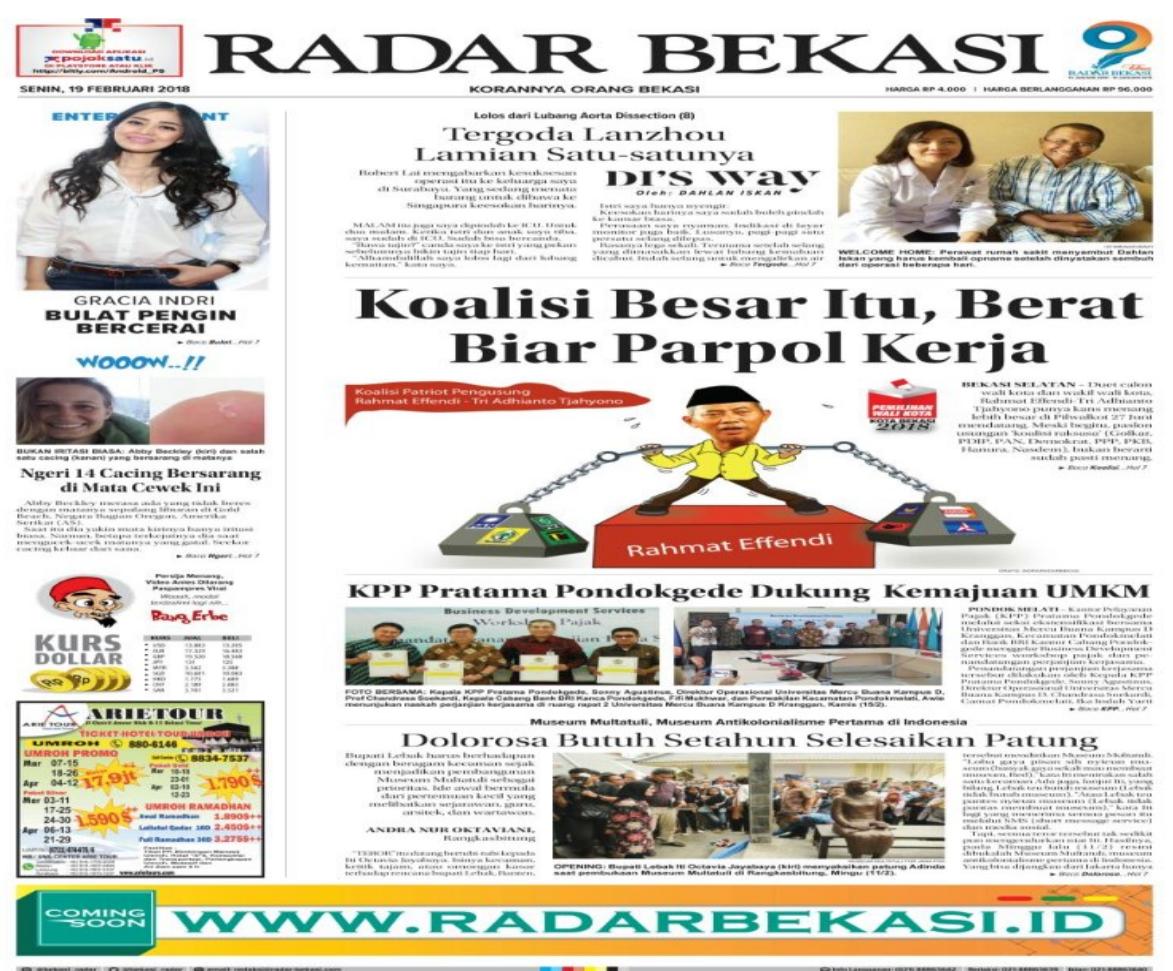

Figure 1. The signing of the MoU and the E Filling and NPWP Tax Workshop Publication (2018)

E-Commerce training in the Business Development Services program was held on Tuesday, May 8, 2018, at 09.00-13.00 at Laboratorium B101, B102 and the University Hall of Mercubuana Campus D, Kranggan Bekasi. For the Pondok Melati UMKM Bazaar, the theme "Mass Marriage and UMKM" was held on Wednesday, May 9, 2018, 9:00 to 13:00 at the Pondok Melati District office, J1. Perum Chandra Indah Jatirahayu Market.

79 participants took part in the Businnes Development Services collaboration activity, which was the Signing of the MoU/ PKS and continued with a Tax workshop with the theme "E-filling and NPWP. Business Development Service (BDS) socialization, attended by 125 participants consisting of UMKM participants in Pondok Melati sub-district; E-Commerce Training in Business Development Services Program, attended by 55 participants consisting of UMKM participants in Pondok Melati District; The bazaar was attended by UMKM participants in Pondok Melati, attended by 22 SMEs.

Meanwhile, the Simple Bookkeeping Training in Business Development Services Program, which was attended by 50 participants, and the Brand Image/ Visual Training in Business Development Services Program, was attended by 42 participants.

\section{RESULT AND DISCUSSION}

SMEs have tremendous potential that has not been worked out optimally. This sector is the most powerful economic force. For this reason, the government and the community have joint responsibility for how to improve the abilities and competencies of MSMEs. So that in the future it can become the foundation of Indonesia's economy.

This Business Development Services (BDS) activity is supported by the Bekasi City Government, Pegadaian, BRI Bank, BUMN Creative House, and Mercu Buana University Campus D, Kranggan and the community. This activity provides benefits to the community and encourages MSMEs to grow. So that small households can prosper independently and reduce the workload of the State Budget (APBN) and the Regional Budget (APBD). The results can be seen with the increasing emergence of productive communities in the Pondok Melati 
region, which in turn was able to make the UMKM Pondok Melati become a professional by forming a management forum and actively participating in the bazaars with a number of provisions that they had themselves such as tents and others. The series of BDS activities were published from the beginning to the end of the activity in the Radar Bekasi newspaper for one year of activities and the Insight magazine of Mercu Buana University Campus D Kranggan Bekasi.

Table 1. Realization of UMKM Taxpayer Reporting at KPP Pratama Pondok Gede

\begin{tabular}{ccc}
\hline Year & Registered UMKM Taxpayers & SPT realization \\
\hline 2016 & 7.254 & 3.146 \\
2017 & 8.880 & 2.866 \\
\hline
\end{tabular}

Source: KPP Pratama Pondok Gede, 2018. Data processed

The role of the Tax office is not only to collect taxes, but also to start inviting how MSMEs can feel the tax money they pay. Because the training conducted by the tax office and partners of the BDS program cooperation agreement is free of charge. Table I shows the growth and increase in the number of MSME practitioners due to the BDS program launched by the government. Although the tax realization has decreased, the potential for the realization of tax revenue in the future will increase. This is the reason for the implementation of the BDS program through training, guidance and assistance for SMEs, so that taxpayer compliance increases. The Bekasi City Government has also provided guidance to young MSMEs in cooperation with Google Singapore. With this BDS program, it is expected that 250 thousand assisted MSMEs can produce products that can have competitiveness and become superior export products.

The obstacle for the contributors in BDS activities marked by the signing of the BDS MoU followed by the Workshop "E-Filling and NPWP is how to synchronize the time agreed upon by the parties as contributors and SMEs to be able to prepare everything more regularly so that training participants can exceed the target set. Whereas Constraints for UMKM participants are irregularities in managing funds and limited capital, inadequate human resources and difficulties in marketing as well as difficulties in the process of recording and calculating funds to perform tax payment obligations.

This activity also provides a long-term target, from participants who are currently still students, especially students of Mercu Buana University, Kranggan, Bekasi. Through this activity it is hoped to be able to understand the country's needs through the role of taxes. So in the future students who follow this agenda will understand very well that paying taxes is important because taxes become the backbone of state revenue. To build an understanding of the culture of paying taxes must take place early on. Starting from the way of thinking in paying addressed to students. We must mutual cooperation to increase the activity of paying taxes, because paying taxes is one form of state defense.

This MSME training activity will direct MSME entrepreneurs to do business with products and more professional management. So that it can boost sales and SMEs will be great if you want to be occupied. In other countries where the government supports BDS programs, such as Sri Lanka and Ethiopia, it has been proven that more productive societies are emerging who are becoming MSME entrepreneurs after going through a series of continuous mentoring (Minda Yirga Beyene, 2018).

This UMKM training activity was enthusiastically welcomed by the SMEs, which was part of the efforts of the Pondok Gede Primary KPP to advance the economy of micro and small businesses (MSMEs) in the district of Pondok Melati. MSME is the backbone of the country's economy. Automatically if the business actors advance, the contribution of MSMEs to the state through the tax given will also be large. 
The Directorate General of Taxes packs the business progress of MSME entrepreneurs with the Business Development Services system. The system is also related to training, consultancy services and advice, marketing assistance, business development information, technology transfer, bookkeeping and tax report management, and promotion of business networks that are stamped by Mercu Buana University lectures of Campus D Kranggan Bekasi, Bekasi tax authorities and the Bank BRI Pondok Gede which gave very satisfying results for the enthusiasm of the SMEs to develop the Indonesian nation.

Steps taken to provide debriefing of SMEs, Mercu Buana University Campus D Kranggan Bekasi and their community are ready to improve the skills of business people through human resources owned by Mercu Buana University. Likewise, the BRI Syariah Bank Pondok Gede is ready to provide education and support in the form of capital to MSME practitioners and this collaboration will be carried out continuously in one year. The Pondok Melati Subdistrict also fully supports the progress of business actors in the Pondok Melati region, namely by the ease of business licensing granted. Furthermore, KPP Pratama Pondok Gede also gave a Workshop on e-filling to SMEs and Mercu Buana University Campus D Kranggan community. There were hundreds of participants who attended the workshop.

\section{CONCLUSION}

The development activities of Small and Medium Enterprises (MSMEs) have a very important role in the Indonesian economy. The government pays great attention to the development of Micro, Small and Medium Enterprises (MSMEs) so that they can potentially increase new supply and competition, develop technology, create new markets, increase employment opportunities and production output, increase the contribution of MSMEs to the country's development.

The development of MSMEs in Pondok Melati District is faced with various problems. The problems are often called management irregularities and limited capital, inadequate human resources and difficulties in marketing as well as difficulties in the process of recording and calculating funds to perform tax payment obligations. All can be resolved and answered with the BDS program for the problems that have become obstacles for MSME entrepreneurs in Pondok Melati District. This BDS activity is very beneficial for UMKM businesses in the future.

\section{Acknowledgements}

The author thanks reviewers for their input and suggestions which helped to contribute to this article. Appreciation is also the author addressed to the parties who are actively involved in BDS program activities and provide data also information. The parties in the BDS cooperation agreement are Mercu Buana University Campus D Kranggan Bekasi along with the civitas, KPP Pratama Pondok Gede, Pondok Melati Subdistrict, BRI Pondok Gede Bank, as well as those who helped support the progress of MSMEs namely the Bekasi City Government, the Cooperative Office and Bekasi UMKM, Pegadaian, BUMN Creative House, and related stakeholders.

\section{References}

Adi, I. Astawa \& I. Taun. (2016). Community Economic Development of the Coastal Area in Gianyar Regency of Bali Province, Indonesia, Journal of Economics and Sustainable Development, 7(24), 118-122.

Akhmad, R. Karsidi, S. Rahayu \& M. Wijaya. (2018). The Role of Government Policy in Smes Facilitating Institutions in Indonesia: A Case Study on Business Development Service Provider, Asian Journal for Poverty Studies, 4(1), 12-15. 
Baur, D. Chiumia, C. Gazzarin \& M. Lips. (2017). Perceived Challenges in Business Development of Smallholder Dairy Farmers in Three Malawian Regions, African Journal of Food, Agriculture, Nutrition and Development, 17(4). 12791-12806.

Eduro, P. Aboagye \& M. Edetor, (2014). Microfinance and Small Loans Centre (MASLOC) as a Model for Promoting Micro and Small Enterprises (MSEs) in the Ashaiman Municipality of Ghana, Journal of Economics and Sustainable Development, 5(28), 5365.

Fatoni \& I. Nurhayati. (2014). Analisis Keserasian Program Layanan Business Development Service-Provider (BDS-P) dengan Peraturan Pemerintah terkait Pengembangan Usaha Mikro Kecil dan Menengah (UMKM) di Jawa Timur, Jurnal Manajemen dan Akuntansi, 3(3), 30-47.

Halili \& L. Hongxi. (2019). E-Commece and Internet Marketing in Yemen: Opportunities and Challenges, European Journal of Business and Management, 11(21), 23-32.

Hutagalung, I \& Ritonga, R. (2018). Pengaruh Iklim Komunikasi dan Komitmen Organisasi terhadap Kepuasan Kerja Pegawai Kecamatan XYZ Bekasi, Jurnal Kajian Komunikasi, $6(2), 72-84$.

Mengstie, B. (2016). Impact of Business Development Services on Performance of Micro and Small Enterprises in East Amhara Region of Ethiopia, European Journal of Business and Management, 8(4), 179-187.

Nwaizugbo, V. Aghara \& P. Oparah. (2013). Co-Creating Business Development Service: A Strategic Marketing Approach for Leveraging the Performance of Small and Medium Enterprises (SMEs) in Nigeria, International Journal of Small Business and Entrepreneurship Research, 1(3), 1-11.

Ombi, S. Ambad \& Bujang, I. (2018). The Effect of Business Development Services on Small Medium Enterprises (SMEs) Performance, International Journal of Academic Research in Business \& Social Sciences, 8(3), 117-130.

Rajeev, M. Afua, B. Mohamed. (2017). Fostering Entrepreneurship Development among Youth for Job Creation through Industrial Development: The Case of Zanzibar Technology and Business Incubator, Huria Journal, 24(2), 46-58.

Ritonga, R., Nugroho, E., Handoko, D. (2019). Struggle of Meaning and the Jokowi Myth in the 2018 Asian Games Opening Video, Jurnal Komunikasi: Malaysian Journal of Communication, 35(1), 137-155.

Ritonga, R., Murwani, E., \& Ritonga, S. (2017) Gender Awareness of Maria Hartiningsih as Daily Kompas Reporter, Jurnal Komunikasi Ikatan Sarjana Komunikasi Indonesia, 2(2), 82-91.

Svogzlys. (2019). New Service Development in the Context of Organization Strategy, European Journal of Business and Management, 11(3), 159-166.

Yirga. (2018). Business Development Service Role in Improving the Performance of SMEs in Case of Selected Manufacturing SMEs in Adama Town, Ethiopia, European Journal of Business and Management, 10 (31), 34-38.

Yusuf, M. (2015). A Study of ICT for Business Services and Human Development in Nigerian Microfinance Institutions, Information and Knowledge Management, 5(12), 24-34. 